Limnological Review 10, 2: 59-65

DOI 10.2478/v10194-011-0007-3

\title{
The variability of phosphorus fractions in sediments of a shallow, restored Antoninek Reservoir (Poznań, Poland)
}

\author{
Renata Dondajewska
}

Adam Mickiewicz University, Jeziory Ecological Station, P.O. Box 40, 62-050 Mosina, Poland, e-mail: gawronek@amu.edu.pl

\begin{abstract}
Spatial and temporal variability of phosphorus (P) fractions content in bottom sediments of a shallow preliminary reservoir was studied in Antoninek, situated in Poznań. Fractions were analyzed at least once in a season (more often in spring and summer) between August 2004 and November 2005 according to the fractioning protocol proposed by Psenner et al. (1988). Circa 10 cm thick sediment layers were collected from three study sites, situated along the main axis of the reservoir. The contribution of $\mathrm{NH}_{4} \mathrm{Cl}_{-} \mathrm{P}_{\text {and }}$ BD-P, i.e. the most accessible fractions biologically was similar at all stations (usually below 10\%). The share of other fractions increased according to the sequence $\mathrm{NaOH}-\mathrm{RP}<\mathrm{NaOH}-\mathrm{NRP}<\mathrm{HCl}-\mathrm{P}<$ Res-P. Only at station 1 the amount of phosphorus related to organic matter was lower than with aluminum. The domination of Res-P fraction indicated that the main part of phosphorus in sediment is biologically unavailable, therefore the intensity of phosphorus loading from sediments shall be low. However, high organic matter content, noted in sediments of Antoninek Reservoir, determined great amount of NaOH-NRP fraction. Both parameters remained under the influence of mats of macroalgae, growing intensively in the reservoir during vegetation season. The role of sediments as a source of phosphorus for water column enlarged, due to increased organic matter decomposition, especially in periods of high water temperature in this shallow reservoir.
\end{abstract}

Key words: bottom sediments, phosphorus fractions, restoration, shallow reservoir

\section{Introduction}

An analysis of contributions of particular phosphorus fractions to total $\mathrm{P}$ in sediments allows to predict possible mechanisms of its retention in reservoir as well as to assess potential release ways and, finally, the role of sediments in ecosystem. Bioavailability of individual fractions is more significant than the amount of phosphorus itself (Kentzer 2001). The examination of these values together with its spatial and seasonal variability is of great importance in preliminary reservoir, created to intensify the river water selfpurification. Sediments, becoming a trap or a source of $\mathrm{P}$, influence the scale of its retention in reservoir (Søndergaard et al. 2003).

The aim of the studies was the assessment of seasonal and spatial variation in $\mathrm{P}$ fractions in bottom sediments of shallow preliminary reservoir to determine its role in the retention or release of this compound.

\section{Study site and methods}

The Antoninek Reservoir is a shallow lowland reservoir, first in a cascade of four preliminary water bodies created on the Cybina River in Poznań (Western Poland). It was established in 1989 in intention to reduce the amount of organic matter and nutrients entering the Maltański reservoir, situated below Antoninek. However, the sedimentation of suspended and organic matter, both allo- and autochtonous caused a significant water depth reduction during 1990s. Restoration measures were carried in 2002 and 2003 and emergent macrophytes together with sediments were removed. Partial improvement of outflowing water quality was achieved, especially in case of oxygen conditions, ammonium and nitrate nitrogen, total $\mathrm{N}$ and total P concentrations (Gołdyn et al. 2009).

Present surface area of the reservoir is 7.2 ha and the mean depth is $0.5 \mathrm{~m}$. Water residency time varied from 0.65 to 38 days in years 2004-2006, while mean water flow rate was $0.32 \mathrm{~m}^{3} \mathrm{~s}^{-1}$ at the Cybina Riv- 


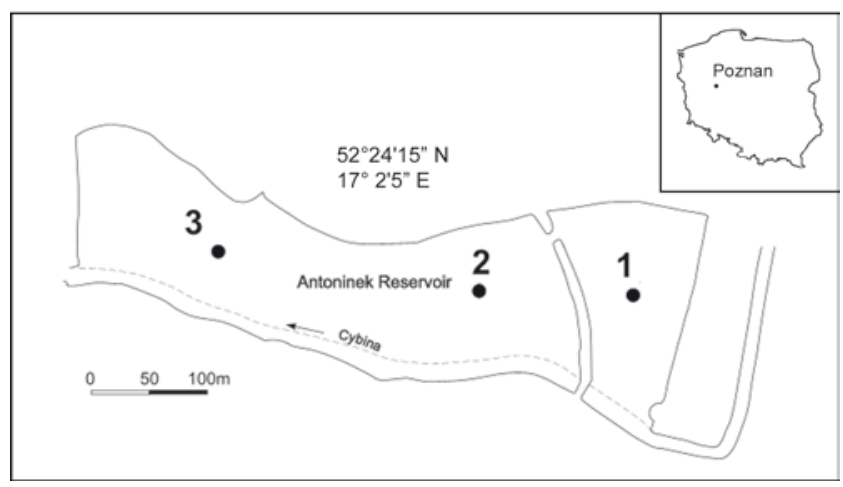

Fig. 1. The location of the reservoir in Poland and the research points in the reservoir (1-3)

er inflow to the reservoir (Dondajewska 2009; Gołdyn et al. 2009), being lower than mean long-term value $\left(0.67 \mathrm{~m}^{3} \mathrm{~s}^{-1}\right)$ (Gołdyn and Grabia 1998).

Sediment samples were collected between $\mathrm{Au}$ gust 2004 and November 2005 with modified Kajak bottom sampler from three research sites (Fig. 1), situated along the main axis of the reservoir. Station 1 was placed by the river inflow, 2 - in the middle of the water body and station 3 - by the outflow. Due to technical problems with bottom sampler, sediments were not gathered in March 2005 at station 3. Surface, ca 10 $\mathrm{cm}$ thick sediment layer was used for analysis. Phosphorus fractions were separated according to the fractioning protocol proposed by Psenner et al. (1988). In a volume of $1 \mathrm{~cm}^{3}$ of wet sediment, following fractions were assayed:

- loosely bound $\mathrm{P}\left(\mathrm{NH}_{4} \mathrm{Cl}-\mathrm{P}\right)$ by extraction with $1 \mathrm{M}$ $\mathrm{NH}_{4} \mathrm{Cl}$ for $2 \mathrm{~h}$;

- P bound with iron (BD-P) by extraction with a mixture $(1: 1)$ of $0.11 \mathrm{M} \mathrm{NaHCO}_{3}$ and $0.11 \mathrm{M}$ $\mathrm{Na}_{2} \mathrm{~S}_{2} \mathrm{O}_{4}$ for $2 \mathrm{~h}$;

- $\mathrm{P}$ bound with aluminum (NaOH-P-RP) and with organic matter $(\mathrm{NaOH}-\mathrm{NRP})$ by extraction with 1 $\mathrm{M} \mathrm{NaOH}$ for $18 \mathrm{~h}$;

- $\mathrm{P}$ in compounds with calcium (HCl-P) by extraction with $0.5 \mathrm{M} \mathrm{HCl}$ for $18 \mathrm{~h}$.

The residue $\mathrm{P}$ (Res-P), i.e. biologically unavailable phosphorus was determined as a difference between total P content and the sum of other fractions. Total $\mathrm{P}$ concentration was analyzed by drying the sample in $150^{\circ} \mathrm{C}$, incineration in $550^{\circ} \mathrm{C}$ and mineralization with $\mathrm{HCl}$. After each stage of extraction, the sample was centrifuged and $\mathrm{P}$ concentration in the supernatant was determined by the molybdate method with the ascorbic acid as the reducer (Elbanowska et al. 1999).

\section{Results}

The highest contribution to total $\mathrm{P}$ characterized Res-P fraction at station $1-0.51 \mathrm{mg} \mathrm{P} \mathrm{g} \mathrm{DW}^{-1}$ on average $(46.7 \%)$. Values below $10 \%$ were noted twice - in March and November 2005 (Fig.1). HCl-P fraction had lower share, but it was various in time (Table 1). Mean value for fraction of $P$ related to aluminum was $16.9 \%$, but it increased significantly in November 2005 to $39.6 \%$, while in other samples it was usually below $14 \%$. Concentrations of $\mathrm{P}$ bound to organic matter (NaOH-NRP) were highest in early spring and autumn ( 14.4 to $19.1 \%$, i.e 0.19 to $0.25 \mathrm{mg} \mathrm{P} \mathrm{g} \mathrm{DW}^{-1}$ ), decreasing in late spring and summer below $10 \%$. Both, loosely-bound and related with iron $\mathrm{P}$ had the lowest contribution in $\mathrm{P}$ pool in sediment. In case of $\mathrm{NH}_{4} \mathrm{Cl}-\mathrm{P}$ most values were below $5 \%$, while for BD-P below 8\% (Fig. 2).

Res-P contribution to total $\mathrm{P}$ at station 2 was slightly higher than at station 1 . Mean value reached $49.9 \%\left(0.52 \mathrm{mg} \mathrm{P} \mathrm{g} \mathrm{DW}^{-1}\right)$. Only in one sample (Nov 2005) the amount of residue $P$ was below 35\% (0.19 $\left.\mathrm{mg} \mathrm{P} \mathrm{g} \mathrm{DW}{ }^{-1}\right)$, while greatest values were noted in June and July 2005 (over 60\%, Fig. 3). The second contributor at station 2 was $\mathrm{HCl}-\mathrm{P}$. Its share in sediment $\mathrm{P}$ pool exceeded 30\% in August and October 2004. The mean

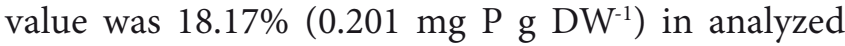
period. The contribution of $\mathrm{NaOH}-\mathrm{NRP}$ was usually lower than $20 \%$, while the average was $13.65 \%$. Highest amount of $\mathrm{P}$ related with organic matter was noted in March 2005 (over 40\%). Other fractions $\left(\mathrm{NH}_{4} \mathrm{Cl}-\mathrm{P}\right.$, BD-P and NaOH-RP) usually contribute below $10 \%$ of total P (Table1). The greatest amount were noted in November 2005 for all three fractions (Fig. 3).

Dominating contribution of Res-P fraction characterized also samples collected at station 3 (Table 1). Very high values were noted in May 2005 and July 2005 (over 78\%, i.e. over $1.0 \mathrm{mg} \mathrm{P} \mathrm{g} \mathrm{DW}^{-1}$ ). Share below 35\% was observed only in November 2005 (Fig. 3 ) and the average was $57.5 \%\left(0.869 \mathrm{mg} \mathrm{P} \mathrm{g} \mathrm{DW}^{-1}\right)$. $\mathrm{HCl}-\mathrm{P}$ fraction content varied from $0.05 \mathrm{mg} \mathrm{P} \mathrm{g} \mathrm{DW}^{-1}$ in May 2005 to $0.45 \mathrm{mg} \mathrm{P} \mathrm{g} \mathrm{DW}^{-1}$ in October 2004. Slightly lower values characterized $\mathrm{P}$ bound to organic matter. Maximum was noted in November 2005 (over 20\%), minimum in July and August 2005 (below 4\%), while the average was $10.5 \%\left(0.12 \mathrm{mg} \mathrm{P} \mathrm{g} \mathrm{DW}^{-1}\right)$. Similar as at station 2, other P fractions usually contribute less than $10 \%$ to total P (Fig. 4, and Table1).

The analysis of spatial changes in $\mathrm{P}$ fractions contribution to total $\mathrm{P}$ in sediment indicated that at 
Table 1. The range of values of phosphorus fractions content and their percentage contribution at each research station

\begin{tabular}{|c|c|c|c|c|c|c|}
\cline { 2 - 7 } \multicolumn{1}{c|}{} & \multicolumn{2}{c|}{$\mathrm{NH}_{4} \mathrm{Cl}-\mathrm{P}$} & \multicolumn{2}{c|}{$\mathrm{BD}-\mathrm{P}$} & \multicolumn{2}{c|}{$\mathrm{NaOH}-\mathrm{RP}$} \\
\cline { 2 - 8 } \multicolumn{1}{c|}{} & $\mathrm{mg} \mathrm{P} \mathrm{g} \mathrm{DW}^{-1}$ & $\%$ & $\mathrm{mg} \mathrm{P} \mathrm{g} \mathrm{DW}^{-1}$ & $\%$ & $\mathrm{mg} \mathrm{P} \mathrm{g} \mathrm{DW}^{-1}$ & $\%$ \\
\hline station 1 & $0.02-0.08$ & $1.6-8.2$ & $0.03-0.23$ & $2.1-17.7$ & $0.05-0.42$ & $4.3-39.6$ \\
\hline station 2 & $0.03-0.11$ & $2.1-8.6$ & $0.03-0.09$ & $1.7-9.8$ & $0.03-0.21$ & $3.4-23.2$ \\
\hline station 3 & $0.02-0.09$ & $1.8-4.4$ & $0.03-0.08$ & $1.9-8.7$ & $0.06-0.20$ & $3.8-17.8$ \\
\hline & \multicolumn{2}{|c|}{$\mathrm{NaOH}-\mathrm{NRP}$} & \multicolumn{2}{c|}{$\mathrm{HCl}-\mathrm{P}$} & \multicolumn{2}{c|}{$\mathrm{Res}^{-\mathrm{P}}$} \\
\cline { 2 - 8 } & $\mathrm{mg} \mathrm{P} \mathrm{g} \mathrm{DW}-1$ & $\%$ & $\mathrm{mg} \mathrm{P} \mathrm{g} \mathrm{DW}^{-1}$ & $\%$ & $\mathrm{mg} \mathrm{P} \mathrm{g} \mathrm{DW}^{-1}$ & $\%$ \\
\hline station 1 & $0.04-0.25$ & $4.0-19.1$ & $0.06-0.60$ & $6.5-39.0$ & $0.09-0.98$ & $8.0-75.1$ \\
\hline station 2 & $0.04-0.36$ & $1.7-41.1$ & $0.08-0.44$ & $3.6-42.0$ & $0.19-1.56$ & $20.3-73.6$ \\
\hline station 3 & $0.04-0.23$ & $2.2-22.8$ & $0.05-0.45$ & $3.9-26.8$ & $0.27-1.60$ & $33.7-81.0$ \\
\hline
\end{tabular}
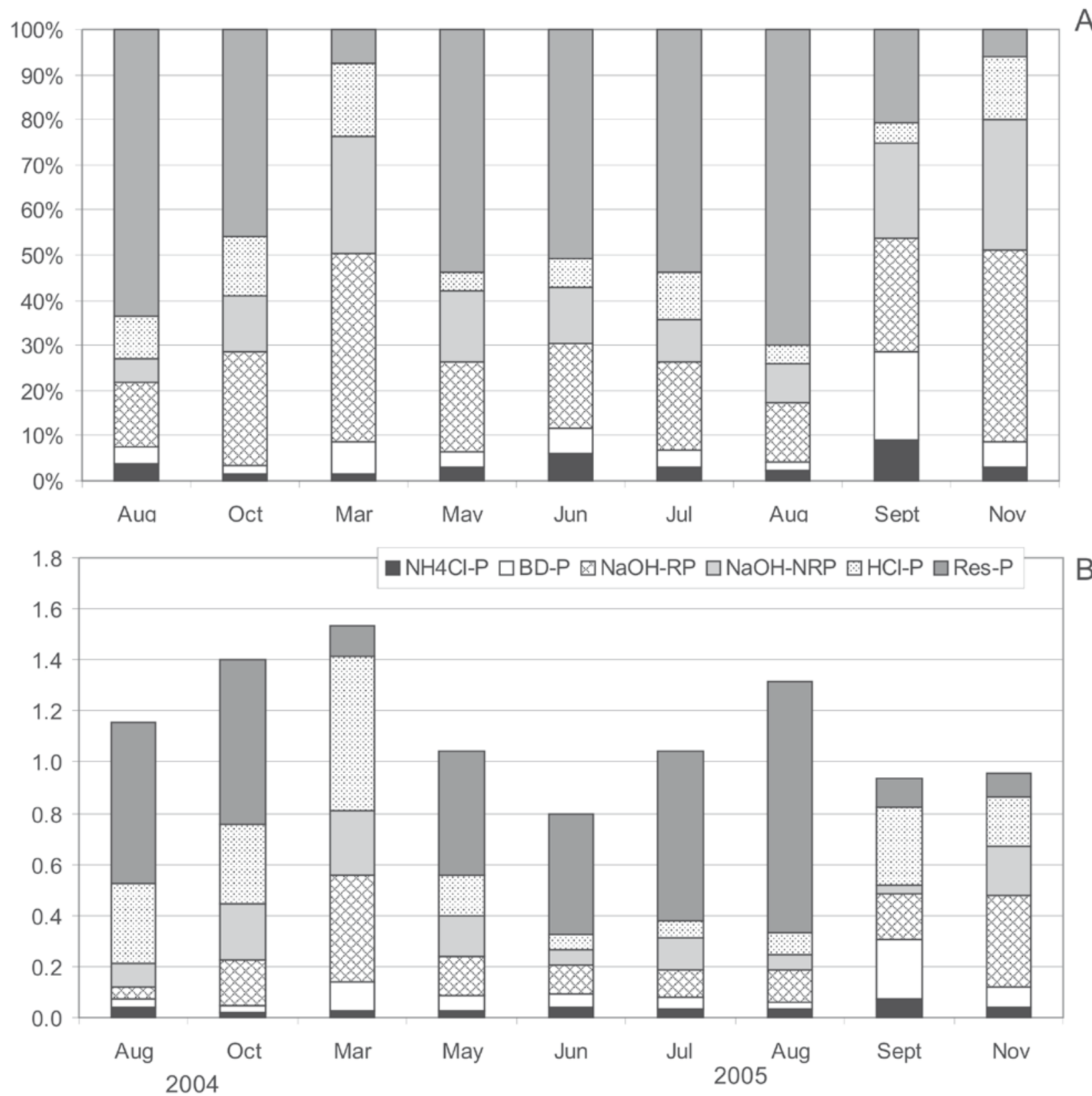

Fig. 2. Phosphorus fractions content at station 1 in the period August 2005-November 2005: percentage contribution (A) and values in mg $\mathrm{P} \mathrm{g} \mathrm{DW}^{-1}(\mathrm{~B})$ 

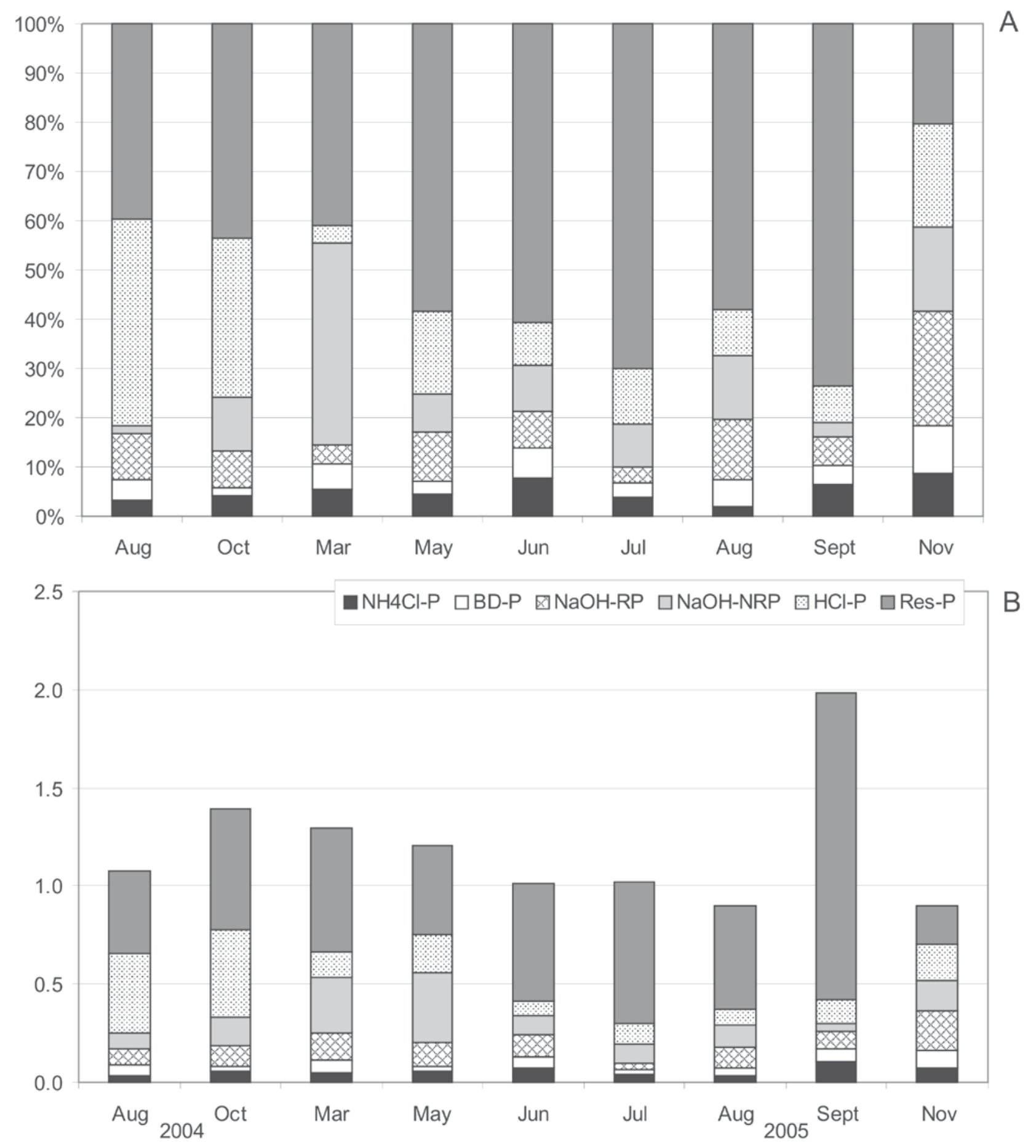

Fig. 3. Phosphorus fractions content at station 2 in the period August 2005-November 2005: percentage contribution (A) and values in mg $\mathrm{P} \mathrm{g} \mathrm{DW}^{-1}(\mathrm{~B})$ 

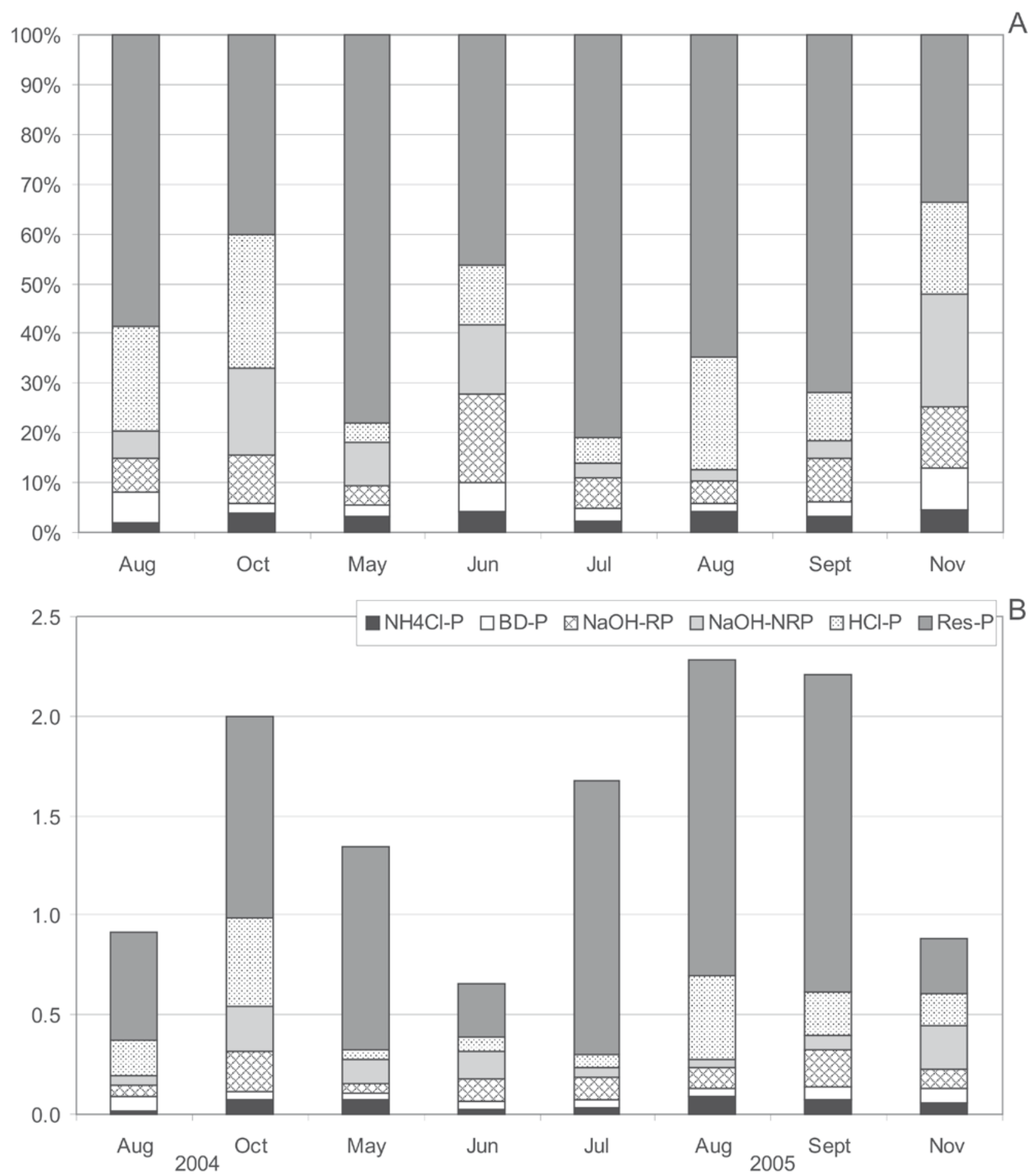

Fig. 4. Phosphorus fractions content at station 3 in the period August 2005-November 2005: percentage contribution (A) and values in mg $\mathrm{P} \mathrm{DW}^{-1}(\mathrm{~B})$ 
all stations fractions $\mathrm{NH}_{4} \mathrm{Cl}-\mathrm{P}$ and $\mathrm{BD}-\mathrm{P}$ were characterized by similar amounts and usually not exceeded $10 \%$. Other fractions share increased according to the sequence: $\mathrm{NaOH}-\mathrm{RP}<\mathrm{NaOH}-\mathrm{NRP}<\mathrm{HCl}-\mathrm{P}<$ Res-P. Station 2 became the only exception of this scheme $\mathrm{P}$ in compounds with organic matter prevailed over $\mathrm{P}$ bound to aluminum. At all stations Res-P was the major contributor, but values varied in time.

\section{Discussion}

Res-P fraction, i.e. phosphorus compounds of the lowest solubility and bioavailability was the major contributor at all stations in Antoninek Reservoir. It is a favourable phenomenon for water quality as it limits the influence of internal loading of $\mathrm{P}$ from bottom sediments. Major part of $\mathrm{P}$ gathered in sediments is inaccessible for living organisms as it is accumulated permanently. Such a high values were also noted in shallow waterbodies, both natural e.g Swarzędzkie Lake (Kowalczewska-Madura et al. 2005) or manmade e.g. Siemianówka (Jekatierynczuk-Rudczyk 2006) in Poland. Great contribution of Res-P might be related to restoration measures carried before analyzed period, when fresh, undecomposed sediments were removed, exposing older, well mineralized sediment. Significant variability in values might be determined by dynamic ecological situation in reservoir, dominated in summer by large mats of filamentous macroalgae (Dondajewska et al. 2007). The amount of organic matter increased periodically as a result of macroalgae deposition in sediments (early spring, autumn) and simultaneously the share of Res-P decreased in sediment sample.

Other phenomenon was also stated at station 1 - the amount of $\mathrm{P}$ fractions related with metals (Fe, $\mathrm{Al}, \mathrm{Ca}$ ) increased during periods with increased water flow (spring, autumn). It indicates greater inflow of these metals with river water, coming from Cybina catchment. The role of the most mobile $\mathrm{P}$ fractions decreased in summer.

Intensive primary production of macroalgae caused high content of organic matter in sediments of Antoninek Reservoir (Dondajewska 2008a), what in consequence resulted in great contribution of $\mathrm{NaOH}$ NRP fraction. Additionally, changes in the biomass of algal mats caused varied content of this fraction in sediments. It increased in autumn (samples from October and November) due to the deposition of organic matter to the sediments. In early spring its amount in sediments was still great, while in May as the water temperature increased, content of $\mathrm{NaOH}-\mathrm{NRP}$ fraction decreased. Phosphorus transformation in sediment was related with microbial enzymatic hydrolysis conducted by bacteria releasing APA (P-alkaline phosphatase) with liberation of orthophosphates (Trojanowska and Izydorczyk 2010). Enzymes dominate in sediment due to access to organic matter: fresh from water column (Jansson et al. 1988) or, as in this case, buried in sediment from decaying filamentous algae from the previous vegetation season. Low contribution of $\mathrm{NaOH}-\mathrm{NRP}$ remained until next autumn. This fraction is therefore a mobile $\mathrm{P}$ fraction, what was already acknowledged (Rydin 2000). Its high share was stated in eutrophicated reservoirs (Sobczyński 2009; Trojanowska and Izydorczyk 2010), what was regarded as a indicator of hydrochemically unstable ecosystems, where $\mathrm{P}$ is easily transported from sediments to water column (Kentzer 2001). Spatial variation in $\mathrm{NaOH}-\mathrm{NRP}$ fraction content was less clear than temporal, however it was noted that the macroalgae mats covered mainly the bottom of middle and lower part of reservoir, where stations 2 and 3 were situated.

HCl-P fraction, i.e. phosphorus bound with calcium is determined mainly by $\mathrm{pH}$ of water and sediments. Quite high $\mathrm{pH}$ values were noted in 2004 (August-October) and in 2005 (March-May) (Dondajewska 2008b) and simultaneously, an increase in the amount of HCl-P fraction was noted. It was a result of orthophosphates precipitation in compounds with $\mathrm{Ca}$ in $\mathrm{pH}$ 7.5-8.5, while the new compounds e.g. $\mathrm{Ca}_{3}\left(\mathrm{PO}_{4}\right)_{2}$ were transformed into insoluble forms, permanently accumulated in sediment. According to Kenzter (2001), the greater is the HCl-P contribution, the more eutrophicated the reservoir is due to increased $\mathrm{pH}$ by intense primary production. Similar values of $\mathrm{HCl}-\mathrm{P}$ share in total $\mathrm{P}$ in sediments were noted in Siemianówka (Jekatierynczuk-Rudczyk 2006) and in Sulejowski Reservoir in Poland (Trojanowska and Izydorczyk 2010).

Low contribution of the most mobile phosphorus fractions, i.e. $\mathrm{NH}_{4} \mathrm{Cl}-\mathrm{P}$ and $\mathrm{BD}-\mathrm{P}$ was a positive phenomenon as it indicated limited possibilities of $\mathrm{P}$ release from bottom sediments. However, literature data report than the share of BD-P fraction shall be greater in shallow and polimictic lake as good oxygen conditions are conducive to create compounds of $\mathrm{P}$ with iron $\mathrm{Fe}^{3+}$ (Kentzer 2001). Maintaining oxygen concentration at high level causes permanent deposition of $\mathrm{P}$ in such form in sediments (i.e. iron-phos- 
phorus cycle). Therefore, low amount of BD-P in Antoninek is rather unexpected as the reservoir is continuously mixed by wind and oxygen deficits occurred only periodically during summer (Gołdyn et al. 2009). Low Fe content might be caused by retention of this compound in Swarzędzkie Lake, situated upstream, however, it is more likely that deoxygenated microlayers formed on the surface of the sediment as a result of intensive organic matter decomposition and, thus, oxygen depletion.

\section{Conclusion}

Seasonal and spatial variability of $\mathrm{P}$ fractions in shallow preliminary reservoir was observed. The amounts of fractions, especially $\mathrm{NaOH}-\mathrm{NRP}$, i.e. phosphorus bound to organic matter changed under the influence of algal mats covering the bottom of the reservoir. However, major part of $\mathrm{P}$ was gathered in sediments in form inaccessible for living organisms as it was accumulated permanently (Res-P and HCl-P fractions).

\section{Acknowledgements}

This study was supported by a grant from the State Committee for Scientific Research, Warsaw, Poland (KBN, no. 3T09D 01527).

\section{References}

Dondajewska R., 2008a, Seasonal and spatial changes in phosphorus and organic matter content in bottom sediments of a shallow reservoir, Limnol. Rev. 8(4): 159-164.

Dondajewska R., 2008b, Funkcjonowanie ekosystemu płytkiego nizinnego zbiornika zaporowego na przykładzie Stawu Antoninek (The functioning of ecosystem of a shallow, preliminary reservoir on the example of Antoninek Reservoir), UAM, The Faculty of Biology, Poznań, p. 256 (dissertation, in Polish).

Dondajewska R., 2009, The role of a shallow lowland reservoir in nitrogen and phosphorus retention, [in:] W. Marszelewski (ed.) Anthropogenic and natural transformations of lakes. Vol.3, PTLim, Toruń: 65-70.

Dondajewska R., Frankowski T., Wojak P., 2007, Changes in vegetation of filamentous green algae in preliminary reservoir Antoninek. Ocean. Hydrobiol. Stud. 36(Suppl. 1): $121-128$.
Elbanowska H., Zerbe J., Siepak J., 1999, Fizyczno-chemiczne badanie wód (Physico-chemical analysis of water), Wyd. Nauk. PWN, Warszawa, p.232 (in Polish).

Gołdyn R., Dondajewska R., Szeląg-Wasielewska E., Szyper H., 2009, An appraisal of changes in seasonal water quality during passage through a shallow reservoir in Western Poland, Environ. Monit. Assess. 151: 181-188.

Gołdyn R., Grabia J., 1998, Program ochrony wód rzeki Cybiny (The program of water protection of the Cybina river), Urząd Miasta Poznania, Wydział Ochrony Środowiska, Poznań, p.101 (in Polish).

Jansson M., Olson H., Petterson K., 1988, Phosphatase origin, characteristics and function in lakes, Hydrobiologia 170: $157-175$.

Jekatierynczuk-Rudczyk E., 2006, Charakterystyka osadów dennych zbiornika Siemianówka (The characteristics of bottom sediments of Siemianówka reservoir), [in:] A. Górniak (ed.) Ekosystem zbiornika Siemianówka w latach 1990-2004 i jego rekultywacja (The ecosystem of Siemianówka reservoir in years 1994-2004 and its restoration), Wyd. UwB, Białystok: 107-118 (in Polish).

Kentzer A., 2001, Fosfor i jego biologicznie dostępne frakcje w osadach jezior o różnej trofii (Phosphorus and its biologically accessible fractions in bottom sediments of lakes of diverse trophic state), Wyd. UMK, Toruń, p.111 (in Polish).

Kowalczewska-Madura K., Jeszke B., Furmanek S., Gołdyn R., 2005, Spatial and seasonal variation of phosphorus fractions in bottom sediments of the hypertrophic Swarzędzkie Lake (W Poland), Limnol. Rev. 5: 123-128.

Psenner R., Boström B., Dinka M., Pettersson K., Pucsko R., Sager M., 1988, Fractination of phosphorus in suspended matter and sediment, Arch. Hydrobiol. Beih. Ergebn. Limnol. 30: 83-112.

Rydin E., 2000, Potentially mobile phosphorus in Lake Erken sediment, Water Res. 34(7): 2037-2042.

Sobczyński T., Joniak T., 2009, Differences in composition and proportion of phosphorus fractions in bottom sediments of Lake Góreckie (Wielkopolska National Park), Environ. Prot. Eng. 35(2): 89-95.

Søndergaard M., Jensen J. P. and Jeppesen E., 2003. Role of sediment and internal loading of phosphorus in shallow lakes, Hydrobiologia, 506-509: 135-145.

Trojanowska A.A., Izydorczyk K., 2010, Phosphorus fractions transformation in sediments before and after cyanobacterial bloom: implications for reduction of eutrophication symptoms in dam reservoir, Water Air Soil Poll. 211(1-4): 287-298. 